\title{
Isolasi dan Karakterisasi Bakteri yang Bersimbiosis dengan Spons
}

\section{(Isolation and Characterization of Symbiotic Bacteria with Sponges)}

\author{
Megawati $^{1 *}$, Meryany Ananda ${ }^{1}$, I Nengah Suwastika ${ }^{1}$ \\ ${ }^{1}$ Laboratorium Biologi Sel dan Molekul, Jurusan Biologi, Fakultas MIPA Universitas Tadulako Jl. Soekarno Hatta km 9 \\ Tondo, Palu 94117, Sulawesi Tengah, Indonesia.
}

Keywords: Isolation, characterization, symbiosis, sponge.

Keywords: Isolasi, karakterisasi, simbiosis, spons.

* Coresponding Author : meegawaty@gmail.com (ph/fax: +62-451-97896)

\begin{abstract}
Abstrak
Bakteri mampu bersimbiosis dengan spons karena memiliki hubungan simbiosis secara mutualisme antara spons dengan bakteri dalam penelitian ini bertujuan memperoleh isolat bakteri dan mengetahui karakteristik bakteri yang bersimbiosis dengan spons, spons diambil di Perairan Teluk Tomini Sulawesi Tengah dengan menggunakan pisau. Sampel kemudian dimasukkan dalam botol steril yang diisi dengan air laut steril dan gliserol $30 \%$. Bakteri pada sampel diisolasi pada media SWC dengan metode spread plate dari hasil isolasi terdapat tiga isolat, isolat terdapat tiga yang isolat yang dilanjutkan untuk ketahap karakterisasi yakni (BS 1, BS 3 dan BS 10).
\end{abstract}

\begin{abstract}
Bacteria are able to symbiosis with sponges because they have a symbiotic relationship between mutual sponges and bacteria in this study aimed at obtaining bacterial isolates and knowing the characteristics of bacteria symbiosis with sponges, sponges taken from Tomini Bay waters in Central Sulawesi using a knife. The sample is then put in a sterile bottle filled with sterile sea water and $30 \%$ glycerol. Bacteria in the sample were isolated on the SWC media with the spread plate method from the isolation results, there were three isolates, the isolates were three isolates which were continued for the characterization stage, namely (BS 1, BS 3 and BS 10).
\end{abstract}

\section{Latar Belakang}

Bakteri mampu bersimbiosis dengan spons karena memiliki hubungan simbiosis secara mutualisme antara spons dengan bakteri. Hubungan ini mempengaruhi siklus biogeokimia dari nutrisi utama seperti karbon, nitrogen dan fosfor sehingga terdapat beberapa jenis bakteri yang bersimbiosis dengan spons (Pita et al., 2018).

Spons Pione vestifica terdapat sembilan genus bakteri yang mampu bersimbiosis dengan spons yakni bakteri Vibrio, Halomonas, Alteromonas Staphyloccus, Pseudtromonas, Tenachibaculun, Spongiobacter, Bacilus dan Pseudovibrio, sedangkan pada jenis spons
Siphonochalinna siphonella terdapat tujuh genus bakteri yang didapatkan diantaranya Pseudovibrio, Photobacterium, Psychrobacter, Halomonas, Kocuria Bacilus dan Carnobacterium (Bibi et al., 2018).

Spons adalah hewan berpori yang termasuk filter feeder yaitu hewan yang memiliki cara makan dengan menyaring air laut melalui pori-pori (ostium). Mikroorganisme atau sisa organisme yang telah mati yang berada di air laut menjadi sumber makanan untuk spons. Tubuh spons yang berpori-pori digunakan bakteri sebagai tempat hidup dan perlindungan dari predator. Hubungan simbiosis spons dan bakteri terjadi secara mutualisme (Taylor et al., 2007). 
Teluk Tomini merupakan teluk yang paling luas di daerah khatulistiwa dengan luas $\pm 59.500 \mathrm{~km}^{2}$ atau \pm 6 juta hektar (Muzakir dan Suparman, 2016). Dengan potensi sumberdaya alam yang sangat besar Teluk Tomini merupakan salah satu kawasan unggulan yang harus dikembangkan dan dikelola dimana pola massa air yang secara alamiah memiliki sistem khusus berupa kesuburan sehingga menjadi habitat yang baik bagi berbagai biota laut seperti padang lamun, mangrove dan terumbu karang dan salah satu biota laut yang ditemukan di Teluk Tomin adalah spons (Suwarso dkk,. 2007). Spons merupakan biota laut yang dapat dimanfaatkan oleh manusia sebagai bahan obatobatan seperti antibakteri, antijamur, antioksidan dan sebagai habitat bakteri untuk perlindungan dari predator.

\section{Bahan dan Metode}

Bahan yang digunakan dalam penelitian ini adalah sampel spons kelas Demospongiae, media Sea Water Complete (SWC), media gula-gula, air laut, aquades dan gliserol.

\section{Pengambilan Sampel}

Pengambilan sampel spons diambil dengan menggunakan alat bantu SCUBA jenis spons yang diambil adalah kelas Demospongiae, pengambilan dilakukan secara purposive sampling yaitu dengan menyusuri dasar laut. GPS digunakan untuk menentukan titik koordinat sampel spons selanjutnya diambil pada kedalaman $4 \mathrm{~m}$, sebelum pengambilan sampel, terlebih dahulu dilakukan pengkuran parameter lingkungan seperti suhu, $\mathrm{pH}$ dan salinitas. Spons diambil dengan dipotong menggunakan pisau, Spons kemudian dicuci dengan air laut steril dan dimasukkan ke dalam botol steril selanjutnya diisi dengan air laut steril dan gliserol 30\% kemudian disimpan dalam cool box berisi es batu (Rizki, 2013). Analisis dilakukan di Laboratorium Biologi Sel dan Molekul, Jurusan Biologi, Fakultas Matematika dan IImu Pengetahuan Alam, Universitas Tadulako.

\section{Isolasi dan Purifikasi Bakteri}

Isolasi bakteri dilakukan dengan menggunakan metode spread plate (sebaran). Sampel spons sebanyak $10 \mathrm{~g}$ di blender sampai hancur kemudian dimasukkan ke dalam Erlenmeyer yang berisi $90 \mathrm{ml}$ air laut. Selanjutnya sampel yang telah di homogenkan diambil sebanyak 1 $\mathrm{ml}$ kemudian dimasukkan ke dalam tabung reaksi yang berisi $9 \mathrm{ml}$ air laut steril selanjutnya pengenceran dilakukan dari $10^{-1}, 10^{-2}, 10^{-3}, 10^{-4}$ dan $10^{-5}$, dari masing- masing pengenceran ditanam pada medium SWC dengan motode sebaran pada cawan petri. Cawan petri kemudian diinkubasi pada suhu $37^{\circ} \mathrm{C}$ selama 24 jam. Jumlah koloni yang tumbuh diamati. Koloni yang berbeda ditumbuhkan pada medium SWC yang baru untuk mendapatkan kultur murni dengan metode streak (goresan) (Pastra dkk., 2012).

\section{Pengamatan Morfologi Koloni}

Sampel bakteri dari pengenceran $10^{-1}, 10^{-2,} 10^{-3,} 10^{-4}$ dan $10^{-5}$ dilakukan pengamatan morfologi koloni dari bentuk, warna, elevasi dan tepi. Pengamatan dilakukan dengan mengacu pada (Cappucino and Sherman, 2008).

Hasil purifikasi diamati dengan menggunakan mikroskop stereo, koloni diamati dari warna, permukaan dan bentuk koloni.

\section{Pengamatan Koloni Pada media tegak dan miring}

Pengamatan koloni pada media tegak menggunakan Media semi padat yang mengadung agar sebanyak $0,3 \%-0,4 \%$ sehingga media menjadi kenyal tidak padat dan tidak begitu cair. Media dimasukkan dalam tabung reaksi sebanyak $7 \mathrm{ml}$ kemudian di inokulasi menggunakan jarum ose needle diinkubasi selama 24 Jam kemudian diamati koloni bakteri pada media tegak (Cappucino and Sherman, 2008).

Media dimasukkan dalam tabung reaksi sebanyak $7 \mathrm{ml}$, media agak dimiringkan sampai padat kemudian di inokulasi menggunakan jarum ose kemudian diinkubasi selama 12 Jam diamati koloni bakteri pada media miring (Cappucino and Sherman, 2008).

\section{Pengamatan Morfologi Sel Bakteri secara Mikroskopis}

Hasil pewarnaan dilihat di bawa mikroskop dengan permbesaran 1000x untuk memperjelas morfologi sel bakteri ditetesi dengan minyak imersi di atas cover glass. Sel bakteri Gram positif akan berwarna ungu hingga biru, sedangkan bakteri Gram negatif akan berwarna merah (Cappuccino and Sherman, 1998).

\section{Uji Fermentasi Karbohidrat}

Uji Fermentasi karbohidrat menggunakan media fenol red, uji ini bertujuan untuk mengetahui metabolisme bakteri, uji glukosa, laktosa dan sukrosa ditandai dengan perubahan warna kuning pada tabung. Bakteri yang diinokulasi berumur 24 jam diinkubasi pada suhu $37^{\circ} \mathrm{C}$ selama 24 jam (Novel dkk., 2010). 


\section{Hasil dan Pembahasan}

Sampel Spons yang telah di ambil dilakukan identifikasi. Sampel diambil di perairan Teluk Tomini Sulawesi Tengah pada titik koordinat $\mathrm{N} 00^{\circ} 02^{\prime} 19.7^{\prime}$ E $120^{\circ} 06^{\prime} 08$. kedalaman $4 \mathrm{~m}$, suhu $37, \mathrm{pH} 7,8$ dan salinitas 30 ppt. Ciri-ciri morfologi spons, bentuk tubuh agak bulat bagian permukaan spons yang kasar berwarna orange. Saluran keluar air (oskula) terlihat jelas namun tidak beraturan karena memiliki ukuran yang lebih besar dan berada pada bagian atas tubuh spons, pada saluran masuk air ke dalam tubuh spons melalui pori-pori kecil (ostia) terlihat kurang jelas, hasil identifikasai sesui dengan (Utami dkk., 2016).

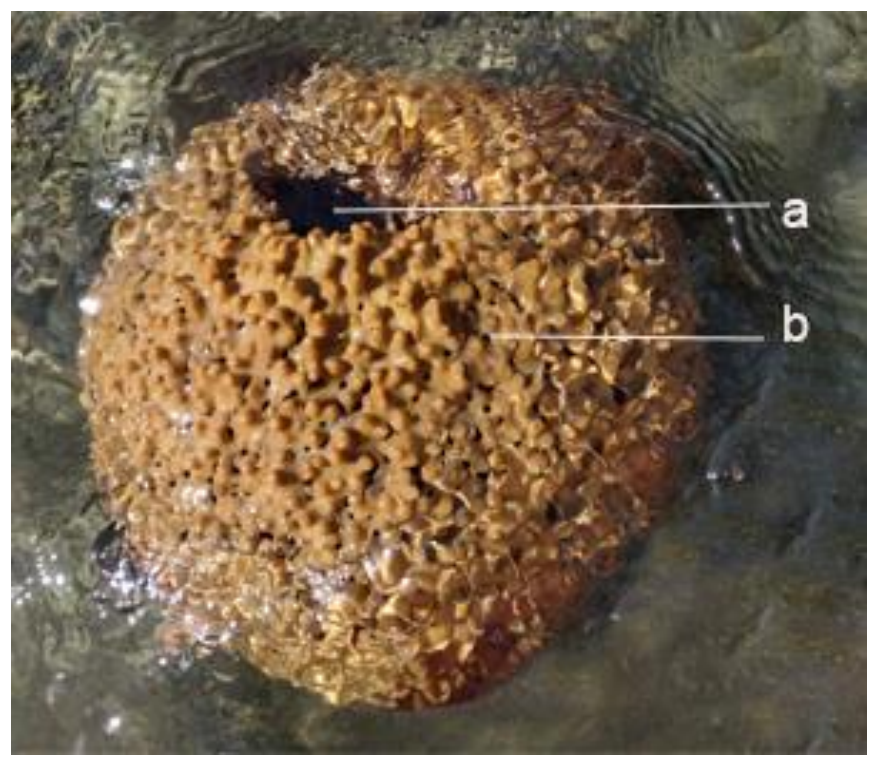

Gambar 1. Kelas Demospongiae: a. Pori-pori kecil (ostia), b: Saluran keluar air (oskula)

\section{Karakter Bakteri yang Bersimbiosis dengan Spons}

Hasil isolasi berhasil dilakukan terdapat tiga isolat bakteri yang berhasil didapatkan dari spons kelas Demospongiae. Tiga isolat tersebut dilanjutkan untuk di purifikasi (pemurnian) dengan menggunakan media SWC Isolat yang didapatkan diberi kode bakteri spons (BS).

Morfologi bakteri diamati secara makroskopis dengan mengacu pada (Cappucino dan Sherman, 1998). Terdapat tiga isolat bakteri yang didapatkan dari spons, karakter koloni terlihat secara beragam. Karakter koloni tersebut didasarkan pada ciri-ciri koloni yang terlihat pada lempeng agar meliputi bentuk, margin, elevasi dan warna. Bentuk koloni terlihat circular (bulat beraturan) pada bagian elevasi raised (rata) dan convex (cembung) sedangkan warna koloni terlihat putih, kream dan kuning, diidasarkan pada (Tabel 1 dan Gambar 2).

Tabel 1. Karakter Morfologi koloni hasil purifikasi dari bakteri yang bersimbiosis dengan spons

\begin{tabular}{llllll}
\hline $\begin{array}{l}\text { No Kode } \\
\text { Isolat }\end{array}$ & $\begin{array}{l}\text { Bentuk } \\
\text { Koloni }\end{array}$ & Elevasi & Margin & $\begin{array}{l}\text { Warna } \\
\text { Koloni }\end{array}$ \\
\hline 1. & BS 1 & Circuler & Raised & Entire & Putih \\
2. & BS 3 & Circuler & Raised & Entire & Kream \\
3. & BS 10 & Circuler & Convex & Entire & Kuning \\
\hline
\end{tabular}

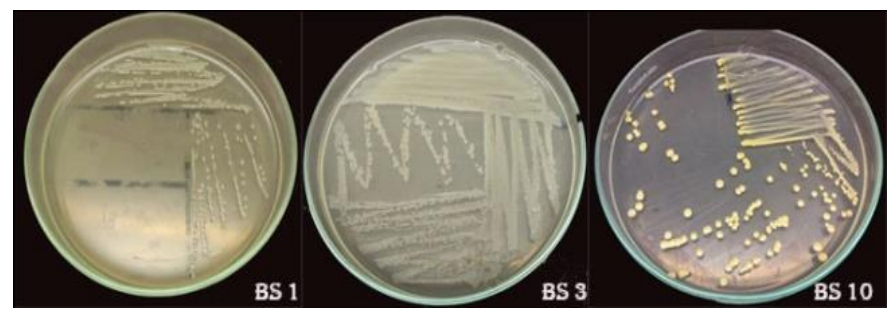

Gambar 2. Hasil purifikasi (pemurnian)

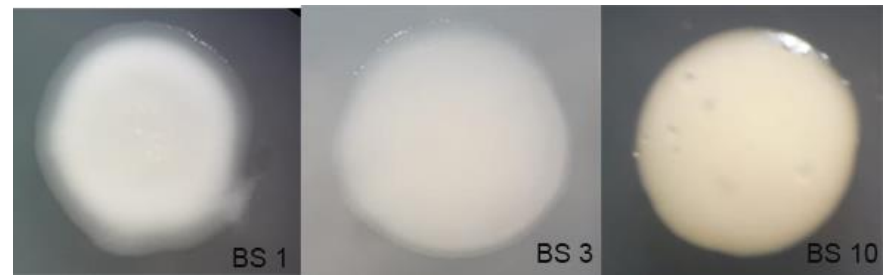

Gambar 3. :Pengamatan Mikroskop Stereo.

Morfologi bakteri diamati secara makroskopis dengan mengacu pada (Cappucino dan Sherman, 1998). Terdapat tiga isolat bakteri yang didapatkan dari spons, karakter koloni terlihat secara beragam. Karakter koloni tersebut didasarkan pada ciri-ciri koloni yang terlihat pada lempeng agar meliputi bentuk, margin, elevasi dan warna. Bentuk koloni terlihat circular (bulat beraturan) pada bagian elevasi raised (rata) dan convex (cembung) sedangkan warna koloni terlihat putih, kream dan kuning, diidasarkan pada (Tabel 1 dan Gambar 2).

\section{Karakter Koloni pada media Tegak dan Miring}

Hasil pengamatan berdasarkan (Cappuccino and Sherman, 2008), terdapat isolat bakteri terlihat villous bentuk pendek tebal bagian permukaan seperti rambut dan isolat echinulate pertumbuhan sepanjang bekas inokulasi bergerigi atau berbintik-bintik.

Media miring mengacu pada (Cappuccino and Sherman, 2008), bentuk isolat echinulate pertumbuhan sepanjang inokulasi bergerigi atau berbintik dan fillform pertumbuhan sepanjang inokulasi. 
Tabel 2. karakter koloni bakteri pada media tegak dan miring

\begin{tabular}{llll}
\hline No & Kode Isolat & Tegak & Miring \\
\hline 1 & BS 1 & Villous & Echinulate \\
2 & BS 3 & Echinulate & Echinulate \\
3 & BS 10 & Echinulate & Fillform \\
\hline
\end{tabular}

Keterangan:

BS 1 :Gram positif bentuk coccus

BS 3 :Gambar positif bentuk coccus

BS 10 :Gram negatif bentuk bacil

\section{Morfologi Sel Bakteri secara Mikroskopis}

Pada penelitian ini bakteri terlihat Gram positif BS 1 dan BS 10 bentuk sel terlihat coccus (bulat) sedangkan BS 3 Gram negatif terlihat bacil (kapsul) didasarkan pada Gambar 3. Menurut (Pelczar dan Chan, 1986), Sekitar $80 \%$ jenis bakteri laut merupakan Gram negatif. Bakteri laut $75-85 \%$ yang ditemukan pada umumnya berbentuk bacil dan memiliki flagel yang digunakan untuk bergerak aktif di perairan sedangkan bakteri yang berbentuk coccus tidak memiliki alat gerak maka hidupnya akan melekat pada suatu substrak termasuk pada spons. Bakteri yang berbentuk coccus karena adanya bahan berlendir sehingga sel-sel saling terikat atau bergabung dengan sesamanya untuk membentuk permukaan yang kuat (solid).

Fermentasi dihasilkan oleh mikroorganisme, uji fermentasi glukosa dan sukrosa menunjukan terjadi fermentasi karbohidrat karena media mengalami perubahan warna, uji fermetasi laktosa tidak terjadi fermentasi disajikan pada (Gambar 4 dan tabel 3). Hal ini dikarenakan laktosa dalam bentuk bebas tidak dapat terikat dengan molekul lainnya hanya dapat ditemukan pada susu. Laktosa dibuat di sel-sel kelenjar mamma pada masa menyusui melalui reaksi antara glukosa dan galaktosa uridin difosfat dengan bantuan laktos synthetase (Sinuhaji, 2006).

Perubahan warna diikuti terbentuknya gas pada tabung durham yang merupakan fermentasi asam campuran dan fermentasi tanpa adanya perubahan warna tetapi terbentuk gas pada tabung durham menandakan terjadinya fermentasi alkohol.
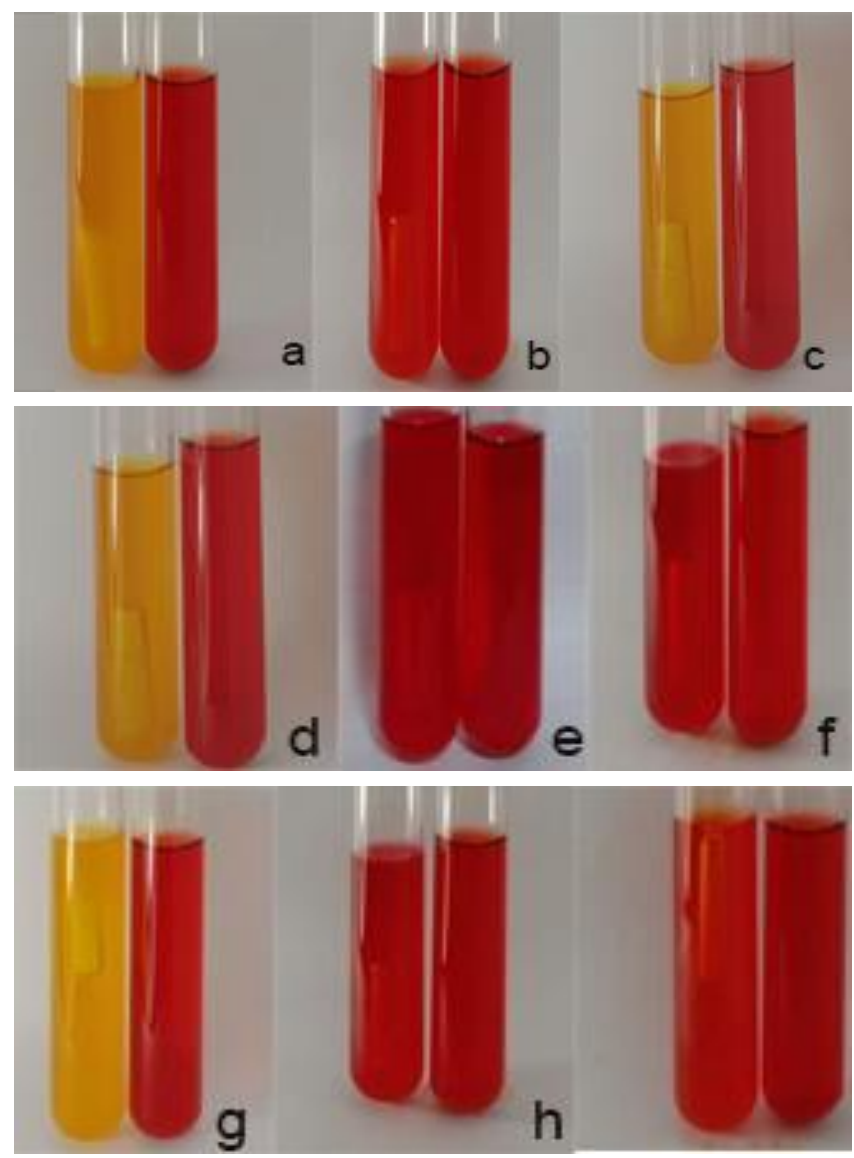

Gambar 4.: Hasil Fermentasi karbohidrat

\section{Keterangan:}

a : Fermentasi glukosa BS 1

b : Fermentasi laktosa BS 1

c : Fermentasi sukrosa BS1

d : Fermentasi glukosa BS 3

e : Fermentasi laktosa BS 3

$f$ : Fermentasi sukrosa BS 3

g : Fermentasi glukosa BS 10

h : Fermentasi laktosa BS 10

i : Fermentasi sukrosa BS 10

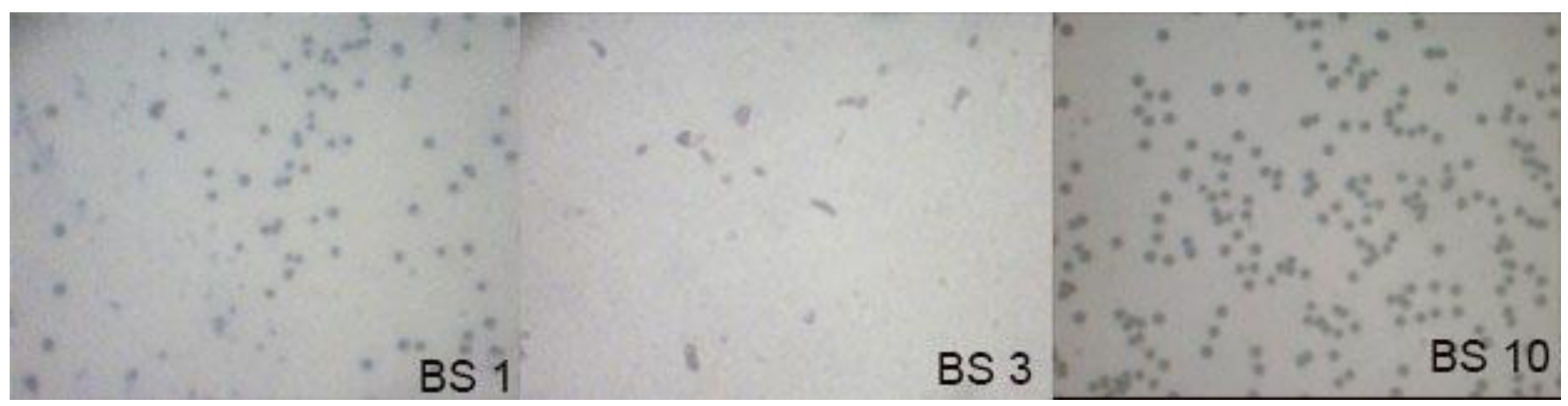

Gambar 4 Sel bakteri mikroskopis 
Tabel 3. Uji Fermentasi Karbohidrat

\begin{tabular}{cccccccc}
\hline & Kode & \multicolumn{2}{c}{ Glukosa } & \multicolumn{2}{c}{ Laktosa } & \multicolumn{2}{c}{ Sukrosa } \\
\cline { 3 - 8 } No & Isolat & $\begin{array}{c}\mathrm{pH} \\
\text { Asam }\end{array}$ & $\mathrm{G}$ & $\begin{array}{c}\mathrm{pH} \\
\text { Asam }\end{array}$ & $\mathrm{G}$ & $\begin{array}{c}\mathrm{pH} \\
\text { Asam }\end{array}$ & $\mathrm{G}$ \\
\hline 1 & BS 1 & + & + & - & + & + & + \\
2 & BS 3 & + & + & - & + & - & + \\
3 & BS 10 & + & + & - & + & - & + \\
\hline
\end{tabular}

Keterangan:

$+\quad: \mathrm{pH}$ asam dan memiliki gas

- $\quad$ : pH tidak asam

Menurut (Lay, 1994), bakteri yang ditumbuhkan dalam media cair yang mengandung karbohidrat, maka hasil fermentasi berupa asam dan gas. Asam yang dihasilkan akan menurunkan $\mathrm{pH}$ media biakan. Pembentukkan asam akan ditandai oleh perubahan warna media menjadi kuning. Hal tersebut mengindikasikan kebutuhan nutrient bakteri berupa beberapa karbohidrat yang berbeda.

Sebagai kesimpulan dari penelitian ini, telah diisolasi 10 bakteri dari jenis yang berbeda yang bersimbiosis dengan spons. Diperlukan uji lanjut identifikasi bakteri hingga diketahui jenis masing-masing, dan potensinya dalam bioteknologi.

\section{Ucapan Terima Kasih}

Penulis mengucapkan Terima kasih kepada Laboran Sami Bukang S.P atas bantuannya selama penelitian.

\section{Daftar Pustaka}

Bibi, F., Alvi, S. A., Al-Sofyani, A., Yasir, M., Kensarah, E. A., and Azhar, E. I. 2018. Two marine spongesassociated cultivable bacteria: Diversity and biological activities. J. Genetics and Molecular Research, 17(2), 1-12.

Cappuccino, J.G. Sherman., 2008. Microbiology: a laboratory manual. 10 th.ed pp 30 .

Cappuccino, J.G., dan Sherman, N. 1998. Microbiology: a laboratory manual. pp 50-51.

Lay, B. W. 1994. Analisis Mikroba di Laboratorium. PT Raja Grafindo Persada. Jakarta. $167 \mathrm{hlm}$.

Muzakir dan Suparman. 2016. Strategy of Developing Tomini Bay or Economic Growth of Coastal
Community in Central Sulawesi, Journal of Economics and Policy, Vol 9 (1) (2016): 96-110.

Novel,S.S., Wulandari.P.A., Safitri.R., 2010. Praktikum Mikrobiologi Dasar, Hal 89.

Pastra, D. A., Melki, M., dan Surbakti, H. 2012. Penapisan Bakteri yang Bersimbiosis dengan Spons Jenis Aplysina sp sebagai Penghasil Antibakteri dari Perairan Pulau Tegal Lampung. Jurnal Maspari, 77-82.

Pelczar, M. J. dan Chan, E. C. S. 1986. Dasar-Dasar Mikrobiologi. Jilid I. Penerjemah Ratna Siri Hadioetomo. UI Press, Jakarta Universitad Indonesia lu Press Terjemahan dari: Elements of Microbiology, Hal 138-144.

Pita, L., Rix, L., Slaby, B. M., Franke, A., and Hentschel, U. 2018. The sponge holobiont in a changing ocean: from microbes to ecosystems. Journal Microbiome, 6(1), 1-18.

Rizki, A. F.M, 2013. Skrining bakteri simbion spons asal perairan pulau polewali dan pulau sarappolompo sebagai penghasil Antibakteri terhadap bakteri patogen pada manusia dan ikan. Skripsi. Fakultas Ilmu Kelautan dan Perikanan. Universitas Hasanuddin Makassar.

Sinuhaji AB., 2006. Intoleransi laktosa. Majalah kedokteran nusantara 39, 4, 424- 429.

Suwarso, S., Sadhotomo, B., \& Wudianto, W. (2017). Perkembangan Perikanan Pelagis Kecil Di Teluk Tomini: Suatu Pendekatan ke Arah Manajemen yang Bertanggung jawab. BAWAL Widya Riset Perikanan Tangkap, 1(6), 233-244.

Taylor, M. W., Radax, R., Steger, D., and Wagner, M. 2007. Sponge-associated microorganisms: evolution, ecology, and biotechnological potential. Journal Microbiology and Molecular Biology, 71(2), 295-347.

Utami, T., Komang, N., Trianto, A., Dan Karna Radjasa, O. 2016. Skrining Senyawa Antibakteri Ekstrak Spons Dari Perairan Kupang, Nusa Tenggara Timur Prosiding Seminar Nasional Tahunan Ke-V Hasil-Hasil Penelitian Perikanan dan Kelautan 